\title{
PENGEMBANGAN PENDIDIKAN KARAKTER DI RA BINA INSANI MUSLIM SELAMA PANDEMI COVID-19
}

\author{
Mia Fitriah El karimah \\ Pendidikan Bahasa Inggris, Universitas Indraprasta PGRI Jakarta \\ Email: el.karimah@gmail.com
}

\begin{abstract}
Abstrak
Pendidikan karakter adalah bekal penting dalam merancang anak usia Taman kanak-kanak dalam menyambut masa depan yang penuh dengan tantangan, baik secara akademis maupun dalam kehidupan berbangsa dan bernegara. Pembelajaran di Roudhotul Athfal Bina Insani Muslim pada kondisi pandemi Covid-19 saat ini menjadi tantangan dalam upaya meneruskan pendidikan karakter walau intensitas perjumpaan guru dan siswa berkurang dan beralih ke ruang-ruang digital. Penelitian ini bertujuan untuk mendeskripsikan pengembangan pendidikan karakter di RA Bina Insani selama pandemi. Instrumen penelitian ini menggunakan pedoman observasi, pedoman wawancara semi struktur dimana peneliti mengupayakan pendapat dan ide-ide narasumber secara lebih terbuka agar permasalahan menjadi jelas. Teknik yang digunakan adalah teknik deskriptif kualitatif. Hasil penelitian bahwa Model pembelajaran RA Bina Insani Muslimi di masa pandemi covid-19 ada empat model; Daring (dalam jaringan), luring (luar jaringan), Home visit (pembelajaran ke rumah 1 kali dalam seminggu) dan School Visit. Pengembangan pendidikan karakter ini dituangkan dalam program harian dan mingguan serta dikawal oleh para guru dengan memberikan lembar control karakter, dan dilanjutkan dengan memberikan apresiasi dan bimbingan bagi yang belum memenuhi kriteria. Karakter yang diuraikan menjadi pembiasaan adalah prilaku keseharian anak baik itu kemandirian, kedisiplinan, dan tanggung jawab.
\end{abstract}

Kata Kunci : RA Bina Insani Muslim, Pendidikan Karakter, pandemi Covid-19

\begin{abstract}
Character education is an important provision in preparing early childhood in facing a future full of challenges, both academically and in the life of the nation and state, learning at Roudhotul Athfal Bina Ibsani Muslim in the current conditions of the Covid-19 pandemic is a challenge in efforts to manage education character even though the intensity of the encounter between teachers and students is reduced and moves to digital spaces. This study aims to describe the development of character education in RA Bina Insani during the Covid-19 pandemic. This research instrument uses observation, semi-structured interviews where the researcher tries to open the opinion and ideas of the informants so that the problem becomes clear. The technique used to analyze the data used a qualitative descriptive technique. The results showed that there are four models of learning model RA Bina Insani Muslimi during the Covid-19 pandemic; Online (online), offline (offline), Home visit (home learning once a week) and School Visit. The results show that the development of character education is outlined in daily and weekly programs and is still escorted by teachers by providing character control sheets, and providing appreciation and guidance for those who do not meet the criteria. The characters developed are the child's personality, independence, discipline, and responsibility.
\end{abstract}

Key Words: RA Bina Insani Muslim, Character Education, Covid-19 Pandemic

\section{PENDAHULUAN}

Sudah setahun lebih kegiatan belajar mengajar secara tatap muka terpaksa dihentikan. Hal tersebut sebagai upaya menekan penyebaran virus corona. Sejak bulan maret tahun 2020 aktivitas pembelajaran tatap muka dialihkan dengan pembelajaran daring (online learning). Praktek online learning dilakukan di berbagai tingkat Pendidikan, baik tingkat sekolah maupun tingkat perguruan tinggi tak terkecuali Pendidikan Anak Usia Dini (PAUD). Raudhatul Athfal Bina Insani Muslim termasuk salah satu bentuk satuan 
pendidikan anak usia dini pada jalur pendidikan formal yang juga melaksanakan pembelajaran daring (online learning). Padahal pembelajaran yang digunakan di PAUD idealnya menggunakan sistem pembelajaran langsung, bermain sambil belajar, akan tetapi dikarenakan adanya banyak kasus yang terpapar virus corona, pembelajaran ditingkat inipun terbatas dan banyak aspek perkembangan peserta didik yang belum maksimal [1]

Adapun visi misi Raudhatul Athfal Bina Insani muslimin atau disingkat dengan RA BIM adalah mewujudkan anak yang sehat, cerdas dan berakhlak karimah dan bertakwa kepada Allah Yang Maha Esa. Sedangkan misinya adalah membentuk sikap anak yang beriman dan bertakwa sedini mungkin, mampu mengembangkan kreativitas anak usia dini dan bersosialisasi dengan bermain; memotivasi bakat, minat, imajinasi anak melalui media sarana dan prasarana dan mengarah pada peletakan dasar yang tepat bagi pertumbuhan dan perkembangan fisik daya pikir, daya cipta, sosial emosional, bahasa dan yang semuanya itu bertujuan sebagai dasar pembentukan pribadi yang sempurna.

Dari visi dan misi di atas, penulis menyimpulkan bahwa RA BIM lebih mengarah pada menguatkan pendidikan karakter siswa. Pendidikan karakter memiliki esensi dan makna yang sama dengan pendidikan moral dan pendidikan akhlak. Tujuannya adalah membentuk peserta didik menjadi priibadi yang baik dan bertanggungjawab. Tujuan Pendidikan karakter selain penanaman nilai dalam diri siswa juga bertujuan untuk meningkatkan mutu penyelenggaraan dan hasil pendidikan di sekolah yang mengarah pada pencapaian pembentukan karakter dan akhlak mulia siswa yang terpadu, dan seimbang sesuai dengan standar kompetensi lulusan [2].
Dalam menerjemahkan pendidikan karakter di sekolah tidak bisa dilakukan secara instan, ada serangkaian proses. Oleh karena itu, pendidikan karakter di sekolah harus memperhatikan beberapa prinsip. Senada yang direkomendasikan Character Education Quality Standards bahwa ada beberapa prinsip-prinsip untuk mewujudkan pendidikan karakter yang efektif dari memasarkan nilai-nilai dasar etika sebagai basis karakter, kemudian mengidentifikasi, memilih pendekatan yang efektif, menciptakan warga sekolah yang memiliki kepedulian, kurikulum yang cakupannya membangun karakter siswa dan mengaktifkan keluarga dan anggota masyarakat sebagai relasi dalam usaha membangun karakter [3]. Pembelajaran daring menjadi sebuah tantangan bagi setiap guru, untuk mampu menciptakan lingkungan pembelajaran dalam upaya perkembangan karakter peserta didik tersebut dengan berbagai keterbatasan. Keterbatasan itu bukan hanya dari fasilitas alat dan media. Namun juga keterbatasan mengontrol para peserta didik. Maka dari itu, perlu strategi dan saling bekerjasama dengan orang tua untuk memaksimalkannya.

Pendidikan moral bukan sekedar mengajarkan mana yang benar mana yang salah. Tetapi bagaimana anak-anak lebih mencintai nilai-nilai yang baik [4]. Strategi Pembelajaran Pendidikan Anak Usia Dini di Masa Pandemi Covid-19 yang ditulis pada jurnal Golden Age Jurnal Ilmiah Tumbuh Kembang Anak Usia Dini tahun 2020, penelitian ini menerapkan strategi pembelajaran guru pada saat pandemi covid dengan pembelajaran jarak jauh dengan metode daring dan luring [5]. Penelitian selanjutnya, menjelaskan permasalahan yang muncul dalam pelaksanaan pembelajaran secara daring dan luring dari media, durasi pembelajaran dan penguasaan aplikasi menjadi problem utama dalam pelaksanaan 
pembelajaran pada PAUD [6]. Persamaan dengan penelitian ini ialah membahas pengembangan pendidikan karakter pada anak usia dini, dan permasalahanpermasalahan dalam pelaksanaan pembelajaran pada masa pandemi.

Adapun pembahasan yang akan dibahas pada penelitian ini yaitu cara guru RA BIM dalam mengembangkan Pendidikan karakter anak pada masa pandemi covid19. Diharapkan penelitian ini menjadi salah satu solusi bagi guru PAUD dalam melaksanakan pembelajaran di tengah pandemi, sehingga tujuan pendidikan tetap berjalan dengan baik

\section{METODE}

Metode penelitian ini adalah deskriptif kualitatif, dengan teknik wawancara semi struktur dimana peneliti mengupayakan pendapat dan ide-ide narasumber secara lebih terbuka agar permasalahan menjadi jelas, cara ini dilakukan kepada seluruh anggota sekolah, baik itu yang menaungi sekolah RA Bina Insani Muslim yaitu yayasan pendidikan Islam Hayatinnur, kepala sekolah, guru, siswa, komite sekolah dan walimurid. Penelitian ini dilakukan dengan partisipan penelitian yang berasal dari anak usia 4-5 pada kelompok A sebanyak 8 orang dan usia 56 pada kelompok B sebanyak 18 orang tahun ajaran 2020-2021. Dalam penelitian yang dilakukan, terdapat beberapa teknik pengumpulan data, dari lembar observasi, catatan lapangan dokumen hasil karya siswa, photo, wawancara, dan penilaian.

\section{HASIL DAN PEMBAHASAN}

Pendidikan karakter memiliki tiga peran utama. Pertama, berperan dalam pembentukan dan pengembangan potensi peserta didik. Pendidikan karakter menata dan membangun potensi siswa agar menjadi lebih baik, baik dalam perilaku dan bersikap. Kedua, berperan dalam pengubahan dan penguatan. Pendidikan karakter membangun dan memperkuat peran keluarga, satuan pendidikan, masyarakat, dan pemerintah untuk ikut bertanggung jawab dalam pengembangan potensi dan pembangunan bangsa menuju bangsa yang maju, mandiri, dan sejahtera. Ketiga, berperan sebagai penyaring. Pendidikan karakter menyeleksi budaya sendiri dan menyaring budaya bangsa lain [7].

Pendidikan karakter pada usia Raudhatul athfal masuk pada tingkatan prakonvesional, jika disesuaikan dengan teori moral Kohlberg, yang dapat dilakukan dan diterapkan mulai dari lingkungan keluarga, lingkungan sekolah, sampai lingkungan masyarakat. Tingkatan dimana tingkah laku anak muncul karena ada reward/hadiah dan punishment/hukuman [8].

Piaget mengklasifikasi perkembangan moral anak menjadi 3 fase yaitu:(1) fase absolut; anak memahami sebuah peraturan yang tidak dapat diubah, karena berasal dari otoritas yang dihormatinya. Seperti aturan orang tua, guru, dan sebagainya. Anak mematuhi peraturan itu dengan alasan menghindari penghukuman atas dirinya. (2) fase realitas; anak menepatkan diri untuk menghindari penolakan orang lain yang sebaya dengannya. Sebuah peraturan orang tua dapat diganti sesuai kesepakatan bersama. Anak akan menyetujui sebuah kesepakatan, jika komunikasi antara keduanya disetujui bersama, sehingga akan muncul rasa bertanggung jawab menaatinya, dan (3) fase subyektif; anak membuat motif/kesengajaan dalam penilaian perilaku [9].

Sebagai contoh pada usia taman kanakkanak, dalam kegiatan main pun guru dapat mengajukan beberapa aturan yang harus ditaati, dan mendiskusikan tentang reward yang akan didapatkan kepada anak 
yang mematuhi aturan, dan punishment yang diberikan kepada anak yang melanggar aturan yang sudah disepakati. Kemampuan anak untuk melaksanakan sebuah aturan selama bermain dapat menjadi indikasi tingkat kepatuhan yang dimiliki anak terhadap aturan yang ada. Orang tua, guru, atau orang dewasa yang ada di sekitar anak sebaiknya mampu membimbing anak untuk mematuhi aturan agar mereka terbiasa untuk selalu taat pada aturan yang ada di sekitarnya [9].

Pada akhirnya dua teori Kohlberg dan Piaget mengantarkan bahwa nanti dalam diri setiap anak setiap perilaku akan ditentukan oleh pertimbangan moral dalam dirinya, bukan karena aturan atau oleh keberadaan orang lain semata; artinya anak akan mulai mencintai akan hal-hal yang baik ketika melihat sebuah karakter buruk, dia akan mencoba untuk menghindarinya meskipun tidak ada orang lain, atau anak akan malu melakukan hal-hal yang tidak terpuji.

Usia Taman Kanak-kanak merupakan usia yang efektif dalam mengembangkan pendidikan karakter mereka, dengan maksud menggali potensi atau berbagai kepribadian yang dimiliki oleh anak. Upaya pengembangan ini dapat dilakukan dengan berbagai cara kegiatan. Kegiatan ini tidak hanya terkait dengan kemampuan afektif, kognitif dan psikomotorik saja, akan tetapi juga di era sebagian besar masyarakat harus tetap di rumah untuk mencegah penularan virus corona, perlu kesiapan guru dalam berbagai aplikasi pembelajaran yang mendukung, tentu membutuhkan berbagai keterampilan, komitmen, dan regulasi diri yang baik, sehingga guru memiliki kesiapan untuk menyelenggarakan pembelajaran secara daring.

Model pembelajaran pada RA Bina Insani Muslim di masa pandemi covid-19 ini ada
4, yaitu Daring (dalam jaringan) misalnya melalui zoom, google meet atau menggunakan video call group WA. Luring (luar jaringan) seperti pengumpulan lembar kerja anak. Home visit (pembelajaran ke rumah 1 kali dalam seminggu). School Visit (kunjungan siswa ke sekolah untuk mengumpulkan tugas sekaligus mereview bacaan iqra dan hafalan) selama pembelajaran daring di rumah masing-masing. Materi-materi pembelajaran yang diberikan guru selama di rumah sebenarnya tidak jauh berbeda dengan materi yang diberikan sebelum terjadinya pandemik atau ketika pembelajaran tatap muka di sekolah.

Ada tiga tema dalam materi yang diberikan yaitu PHBS (perilaku Hidup Bersih dan Sehat), perilaku baik dan keagamaan. Materi PHBS contohnya pembiasaan selalu cuci tangan, mandi pagi walaupun tidak ada aktivitas yang mengharuskan ke luar, gosok gigi, membersihkan perlengkapan makan sendiri. Materi pendidikan karakter misalnya pembiasaan membantu orang lain yang ada di sekitar anak, pembiasaan untuk selalu berbicara santun dan sopan, selalu mengucapkan terima kasih jika terbantu atau diberi sesuatu, selalu mengucapkan minta tolong jika butuh bantuan. Sedangkan materi keagamaan contohnya wudhu, sholat, membaca iqro, hafalan surat pendek, berdoa sebelum beraktivitas, dan sebagainya. Materi tersebut sesuai dengan kurikulum yang saat ini digunakan, yaitu kurikulum 2013.

Berdasarkan instrumen pengumpulan data yang digunakan pada penelitian ini, didapatkan kumpulan data yang menunjukkan ragam pencapaian anak baik kelompok A dan kelompok B pada materi pendidikan karakter selama pandemi. 
Tabel 1. Hasil Penilaian Pendidikan Karakter kelompok A

\begin{tabular}{llccc}
\hline \multirow{2}{*}{ No } & \multicolumn{2}{c}{ Materi } & \multicolumn{3}{c}{ Nilai-nilai Karakter } \\
& & Mandiri & Disiplin & Tanggung Jawab \\
\hline 1 & PHBS & $63 \%$ & $50 \%$ & $50 \%$ \\
2 & Pembiasaan baik & $50 \%$ & $50 \%$ & $75 \%$ \\
3 & Keagamaam & $88 \%$ & $88 \%$ & $88 \%$ \\
\hline
\end{tabular}

Hasil penilaian pada kelompok A pada aspek kemandirian, berdasarkan Tabel di atas maka terlihat dari 8 anak, yang mampu melakukan perilaku PHBS sebanyak 5 anak, untuk aspek kedisiplinan dan tanggung jawab sebanyak 4 anak. Sedangkan untuk materi pembiasaan baik sebanyak 4 anak, sedangkan aspek tanggung jawab sebanyak 6 anak. Pada materi keagamaan pada semua aspek yang melakukan dengan tepat waktu dan tanpa disuruh dilihat dari aspek kemandirian, kedisiplinan dan kemandirian sebanyak 7 orang.

Tabel 2. Hasil Penilaian Pendidikan Karakter Kelompok B

\begin{tabular}{clccc}
\hline \multirow{2}{*}{ No } & \multicolumn{2}{c}{ Materi } & \multicolumn{3}{c}{ Nilai-nilai Karakter } \\
& & Mandiri & Disiplin & Tanggung jawab \\
\hline 1 & PHBS & $56 \%$ & $56 \%$ & $56 \%$ \\
2 & Pembiasaan baik & $61 \%$ & $61 \%$ & $67 \%$ \\
3 & Keagamaam & $88 \%$ & $88 \%$ & $88 \%$ \\
\hline
\end{tabular}

Pada Tabel hasil penilaian pada kelompok $\mathrm{B}$, dari 18 anak, yang mampu melakukan perilaku PHBS sebanyak 10 anak, baik dilihat dari aspek kemandirian, kedisiplinan dan tanggung jawab. Sedangkan untuk materi pembiasaan baik sebanyak 11 anak dilihat dari aspek kemandirian dan kedisiplinan, sedangkan aspek tanggung jawab sebanyak 12 anak. Pada meteri keagamaan yang melakukan dengan benar dan tepat waktu sesuai arahan guru sebanyak 17 orang.

Penerapan pendidikan karakter di RA Bina Insani Muslim dituangkan dalam program harian, yaitu tentang kepribadian anak, kemandirian, kedisiplinan, dan tanggung jawab sehingga walaupun hanya dua kali bertemu guru, setiap anak merasa selalu dibimbing pada setiap kegiatannya. Adapun teknis pembelajarannya dimana kelompok A dan B, dibagi menjadi beberapa kelompok, biasanya anak dibagi menjadi empat kelompok, dengan 3 anggota dan masing-masing kelompok melakukan kegiatan yang berbeda-beda. Dalam satu kali pertemuan, anak harus menyelesaikan 2-3 kegiatan dalam kelompok secara bergantian. Adapun tema pembelajaran lebih fokus pada pembentukan karakter anak. Seperti pembelajaran menekankan pengenalan nilai-nilai moral dan perilaku di samping pengembangan motorik melalui kegiatan bermain, pengembangan pengetahuannya melalui kegiatan penggalian potensi dan kepribadian anak-anak.

Pembelajaran daring berupa pengenalan akan sesuatu, dan anak dirangsang untuk dapat berpikir kritis analitis dan problem solving serta pengembangan sosial emosional mereka, pengembangan bahasa juga menjadi target progress anak-anak dalam meningkatkan kemampuan berbahasa mereka dalam menyampaikan sesuatu dengan jelas dan runtut, sedangkan bidang tumbuh kembangnya seni, guru memberikan contoh menyanyi melalui video tutorial atau membuat karya. Dalam pelaksanaan pembelajaran di rumah tidaklah semudah yang dibayangkan. Faktor kurangnya semangat anak, sibuknya orang tua sehingga pendampingannya 
kurang maksimal, kurang variatifnya guru dalam berinovasi dan hanya berorientasi pada penyelesaian materi saja, menjadi sebuah tantangan dalam pembelajaran pada masa pandemi ini.

Dari hasil wawancara guru-guru RA Bina Insani Muslim, ternyata tidak semua orang tua bisa seperti guru di sekolah. Banyak orang tua belum mampu konsisten dalam membimbing anak-anaknya karena kesibukan mereka. Sedangkan wawancara dengan Komite sekolah sebagai lembaga mandiri yang beranggotakan orangtua/wali peserta didik juga berpendapat bahwa banyaknya orang tua yang kerepotan seperti banyaknya tugas yang diberikan oleh sekolah, pendampingan maksimal untuk anak sehari-hari tentu membuat kewalahan para orangtua yang memiliki tingkat kesibukan yang tinggi di rumah, terlebih bagi mereka yang harus tetap bekerja di luar. Ditambah bahwa pendampingan di rumah lebih mengarah pada segi intelektual atau kognitif saja.

Permasalahan lain yang dialami guru adalah berkaitan dengan evaluasi berupa pemantauan dan pengamatan. Selama pandemi Covid-19, pengamatan hanya bisa dilakukan dengan melihat video dan foto yang dikirimkan oleh orang tua murid. Hal ini menyebabkan aktivitas pengamatan yang dilakukan oleh guru menjadi sangat terbatas, pembiasaan ibadah sholat dhuha, hafalan dan iqra penilaiannya terpatok hanya ketika guru dan peserta didik tatap muka yakni seminggu sekali. Sekarang dengan situasi ini guru tidak bisa mengulang-ulang lagi hafalannya, sehingga progress ini kurang signifikan. Penilaian dengan catatan anekdot yang berfungsi sebagai jurnal kegiatan harian juga terhambat, padahal catatan ini untuk mengetahui perkembangan anak. Alhasil dengan adanya keterbatasan pengamatan, bisa dipastikan pencatatan anekdot tidak berjalan maksimal. Hal ini tentunya akan berpengaruh pada validitas penilaian yang dilakukan guru.

Dari beberapa permasalahan yang diungkapkan oleh guru dan kondisi orang tua murid di atas, dapat disimpulkan bahwa pelaksanaan pembelajaran dengan pembentukan karakter anak tidak berjalan dengan mudah. Peran orang tua dan kontribusinya untuk selalu mendampingi dan melaporkan kegiatan anak sangat vital dalam penerapan pembelajaran di rumah. Tetapi belum diikuti dengan pemahaman yang cukup tentang bagaimana mendampingi dan membimbing anak sesuai kaidah-kaidah pendidikan usia dini, pengamatan terbatas yang menyebabkan validitas penilaian berkurang, menjadi masalah yang krusial dialami guru pada proses penerapan Pendidikan karakter pada masa covid-19.

Guru RA Bina Insani Muslim diharapkan tetap bisa optimal menjalankan peran dalam masa pandemi ini, hasil penelusuran bahwa Guru RA Bina Insani Muslim menggunakan satu diantara aplikasi daring seperti Zoom, Google meeting atau video call yang walaupun dilakukan seminggu 2 kali, masih ada beberapa peserta didik yang tidak bergabung.

RA Bina Insani Muslim memang memfasilitasi anak-anak mendapatkan lingkungan sosial yang sesuai dengan masa perkembangan mereka. Para guru memberikan stimulasi dan mendorong mereka untuk belajar berkomunikasi dan mengungkapkan sesuatu; guru juga memberikan bimbingan mengenai cara berbicara yang baik dan sopan, beberapa aktivitas seperti bermain dan bernyanyi juga bermanfaat menambah kosa kata anak. Hal ini akan meningkatkan keterampilan berbicara dan berbahasa. Sementara perhatian khusus secara individual bisa dilakukan ketika homevisit 
dengan membetulkan perilaku yang salah pada siswa [10].

Peran dan fungsinya orang tua dalam bersinergi dengan guru dalam pengembangan pendidikan karakter anak memang mendukung keberhasilan proses ini secara daring. Oleh karena itu guru, orang tua atau keluarga di rumah harus siap menjadi model dan teladan bagi anak dalam membentuk karakter yang baik [11].

Pada materi PHBS anak senantiasa dapat menjaga kebersihan diri, anak mampu menerapkan protokol kesehatan dalam lingkungan keluarga serta anak bisa ikut berperan dalam upaya mencegah penularan virus corona. Pengembangan karakter anak dalam meningkatkan kemandirian mereka, adalah dimulai dari bagaimana anak harus mengatur waktunya setiap hari, dari bertanggung jawab akan diri sendiri, dimulai dari bangun tidur, sholat subuh, mandi dan melaksanakan tugasnya sebagai seorang murid RA Bina Insani Muslim, yakni belajar walaupun terdapat banyak distraksi ketika belajar di rumah.

Mendidik karakter, menurut Lickona dimana pendidik akan melewati 3 aspek dalam kepribadian manusia yaitu moral knowing, moral feeling or attitudes, dan moral behavior. Karakter yang baik dimulai dari anak mengetahui yang baik, melakukan dan membiasakan yang baik pula, yakni akan menjadi pembiasaan tanpa harus didoktrin apalagi diperintah secara paksa. Jika anak terbiasa dengan kebersihan, maka hal-hal yang mengganggu kecintaannya akan kebersihan akan ia singkirkan. Senada dengan William Kilpatric bahwa keberhasilan pendidikan karakter sangat ditompang dengan knowing, loving dan doing dalam proses penyelenggaraan pendidikan karakter [12].
Dari uraian di atas, dapat disimpulkan bahwa metode pembelajaran yang digunakan baik secara konvensioal maupun pembelajaran daring. Pendidikan karakter itu untuk butuh proses, selain pengetahuan, keinginan untuk melakukan akan menjadi sebuah pembiasaan.

Pendidikan karakter melalui PJJ di saat peserta didik belajar dari rumah, harus tetap dikawal dan dikontrol oleh para guru. Salah satunya dengan memberikan lembar control karakter yang diberikan kepada wali murid sebagai laporan perkembangan peserta didik pada akhir semester, yang dikembangkan oleh guru sesuai kompetensi inti dari kurikulum 2013 seperti memiliki sifat religius, jujur, disiplin, tanggung jawab, peduli, toleransi, gotong royong, santun, percaya diri dan lain-lain. Tetapi laporan perkembangan peserta didik pada masa pandemi ini lebih diarahkan pada penguatan karakter kemandirian, kedisiplinan dan tanggung jawab. Lembar kontrol tersebut dinilai setiap minggu oleh guru, pada saat tatap muka. Dan kemudian menguatkan karakter yang sudah baik dan mengubah karakter yang buruk dengan bimbingan antara guru dan orang tua. Di samping itu, penilaian karakter selama pandemi ini, gurupun memberikan penghargaan kepada peserta didik yang terdapat peningkatan dalam berperilaku baik atau setidaknya minimalnya mengucapkan selamat (congratulation) di group WA peserta didik. Di sinilah sebuah apresiasi sekaligus monitoring harus diterapkan oleh para pendidik, karena ini adalah asas pendidikan yang utama [13].

\section{SIMPULAN}

RA Bina Insani Muslim Bekasi Jawa Barat yang selanjutnya disebutkan dengan RA BIM, telah membimbing anak-anak usia Taman Kanak-kanak untuk membiasakan berperilaku baik pada masa pandemi, walaupun bimbingan gurunya 
selama ini terbatas, hanya berapa kali tatap muka selebihnya online, peran dan kerjasama orang tua sangat menentukan hasil pencapaian tersebut, guru dan orang tua diharapkan membangun komunikasi dan interaksi setiap waktu untuk meningkatkan kualitas pembelajaran anak dalam mewujudkan penguatan karakter anak. Teknis pembelajaran selama ini menggunakan 4 cara; daring luring, home visit dan school visit. Dengan mengontrol seminggu sekali dengan memberikan lembar kontrol. Untuk pengamatan dan penilaian belum maksimal karena kondisi yang tidak memungkinkan.

\section{DAFTAR PUSTAKA}

[1] A. N. Fadlilah, "Strategi Menghidupkan Motivasi Belajar Anak Usia Dini Selama Pandemi COVID-19 melalui Publikasi," Obs. J. Pendidik. Anak Usia Dini, vol. 5, no. 1, p. 373, 2020.

[2] M. dan H. Samani, Konsep dan Model Pendidikan Karakter. Bandung: Remaja Rosdakarya, 2011.

[3] R. Putry, "Nilai Pendidikan Karakter Anak di Sekolah Perspektif Kemendiknas," Gend. Equal. Int. J. Child Gend. Stud., vol. 4, no, pp. 3954, 2019.

[4] Sudaryanti, "Pentingnya Pendidikan Karakter bagi Anak Usia Dini," $J$. Pendidik. Anak, vol. 1, pp. 11-20, 2012.

[5] E. Suhendro, "Strategi Pembelajaran Pendidikan Anak Usia Dini di Masa Pandemi Covid-19," J. Golden Age J. Ilm. Tumbuh Kembang Anak Usia Dini, vol. 5, no. 3, pp. 135-140,
2020.

[6] S. A. Harahap, Dimyati, E. Purwanta, "Problematika Pembelajaran Daring dan Luring Anak Usia Dini bagi Guru dan Orang tua di Masa Pandemi Covid 19," J. Obs. J. Pendidik. Anak Usia Dini, vol. Volume 5, no. Issue 2, pp. 18251836, 2021.

[7] Zubaidi, Desain Pendidikan Karakter. Jakarta: Kencana Prenada Media, 2011.

[8] F. L. K. Nida, "Intervensi Teori Perkembangan Moral Lawrence Kohlberg dalam Dinamika Pendidikan Karakter," Edukasia J. Penelit. Pendidik. Islam, vol. 8, no. 2, pp. 271-290, 2013.

[9] A. A. Gunadi, "Membentuk Karakter Melalui Pendidikan Moral pada Anak Usia Dini di Sekolah Raudhatul Athfal (R.A) Habibillah," J. Ilm. Widya, vol. 1, no. 2, pp. 8591, 2013.

[10] A. dan D. A. Majid, Pendidikan Karakter Perspektif Islam. Bandung: Remaja Rosda Karya, 2011.

[11] L. Suryani, Metode Pengembangan Perilaku dan Kemampuan Dasar Anak Usia Dini. Jakarta: Universitas Terbuka, 2012.

[12] A. Sudrajat, "Mengapa Pendidikan Karakter?," J. Pendidik. Karakter, Tahun I, No. 1, pp. 48-58, 2011.

[13] M. Khaironi, "Pendidikan Karakter Anak Usia Dini," J. Golden Age Univ. Hamzanwadi, vol. 1, no. 2, pp. 82-89, 2017. 